University of Wollongong

Research Online

Faculty of Law, Humanities and the Arts Papers (Archive)

Faculty of Arts, Social Sciences \& Humanities

$1-1-2018$

Divided sisterhood? Nationalist feminism and feminist militancy in England and Ireland

Sharon Crozier-De Rosa

University of Wollongong, sharoncd@uow.edu.au

Follow this and additional works at: https://ro.uow.edu.au/lhapapers

Part of the Arts and Humanities Commons, and the Law Commons

Research Online is the open access institutional repository for the University of Wollongong. For further information contact the UOW Library: research-pubs@uow.edu.au 


\title{
Divided sisterhood? Nationalist feminism and feminist militancy in England and Ireland
}

\author{
Abstract \\ The generally accepted story is that British militant suffragists performed an unexpected and abrupt \\ move away from the feminist movement and towards a fiercely jingoistic nationalist campaign once the \\ war began in 1914. Yet, given the nature of exchanges between Irish and British militant feminists, Irish \\ feminists should not have been surprised by this turn from gender solidarity to English nationalism. In this \\ article, I argue that Irish-British militant feminist entanglements worked to expose the powerful role that \\ English nationalism played in suffrage politics at a time when nearly all the focus was on the disruptive \\ influence of Irish nationalism.

\section{Disciplines} \\ Arts and Humanities | Law

\section{Publication Details} \\ Crozier-De Rosa, S. (2018). Divided sisterhood? Nationalist feminism and feminist militancy in England \\ and Ireland. Contemporary British History, 32 (4), 448-469.
}




\section{Sharon Crozier-De Rosa, 'Divided Sisterhood? Nationalist Feminism and Feminist Militancy in England and Ireland', Contemporary British History, Published online: 08 Oct 2018: https://doi.org/10.1080/13619462.2018.1519415}

\section{Introduction}

In July 1912, three English militant suffragists - Mary Leigh, Gladys Evans and Lizzie Baker (Jennie Baines) - travelled to Ireland where, in what is now a renowned display of suffragette ${ }^{1}$ activism, they threw a small hatchet at Herbert Asquith, visiting British prime minister, and John Redmond, leader of the Irish Parliamentary Party, who were meeting to discuss the issue of Irish Home Rule. Later, they also set fire to Dublin's Theatre Royal where Asquith was due to speak. The three women were arrested, tried and accorded heavy sentences for their militancy - five years penal servitude in Leigh's and Evans's cases before undergoing the strains of a hunger strike and the brutality of force feeding while incarcerated in Ireland. The women were members of the British organisation, the Women's Social and Political Union (WSPU), and they had not consulted Dublin-based militant suffragists, members of the Irish Women's Franchise League (IWFL), before undertaking either action. Members of the IWFL, far from condoning the actions of Leigh, Evans and Baines, were angered and frustrated that members of the British organisation had conducted a brief violent campaign in Ireland without considering either the volatility of nationalist and Unionist relations there or the leanings and strategic outlook of Irish suffragists, who were, like Irish men, divided along nationalist and Unionist lines with the result that the Irish suffrage movement was highly fractured. The actions of English militants in Ireland only served to exacerbate anti-suffragist sensibilities on the island as the Irish suffrage movement came to be tainted by its supposed collusion with a British militant feminist movement that was becoming increasingly opposed to Irish nationalist aspirations. The decision made by the English women to ignore Irish women while carrying out suffrage militancy in Ireland also had the effect of exacerbating what was already an uneasy alliance between Irish suffrage militants and their British counterparts.

Irish and British suffragists were allied in many ways. Indeed, to observers at the time, it surely seemed that both campaigns were inextricably linked. Both movements were, of course, embedded within the left-wing political cultures of their respective countries. The WSPU grew out of the British labour movement: its founders, although mainly middle-class, were all members of the Manchester branch of the Independent Labour Party (ILP), and socialist leader and Labour Member of Parliament, Keir Hardie, had even raised $£ 300$ to help the suffrage organisation establish itself. ${ }^{2}$ On the Irish side, the IWFL was located at the radical end of the left-wing spectrum, advocating, as it did, not only radical feminism but also increasingly a radical anti-colonial strain of Irish nationalism that was at odds with the ideas of the more moderate Home Rule nationalists. Women on both sides of the Irish Sea were further connected by the fact that they were ruled by the same male British parliament over which they had no control. Their desire to empower women through enfranchising them made them part of the same network of suffrage activists. English and Irish women 
referenced each other's campaigns, exchanged funding, ideas and approaches, and travelled across national spaces. Those who shared a commitment to using militant tactics were also arrested and imprisoned across those various national spaces. ${ }^{3}$ Both groups of women acknowledged the role that Irish nationalist politics had and was continuing to play in their cross-border feminist campaigns. Irish and British suffrage militants admitted that they had modelled their methods on the politically aggressive and often violent actions of successive waves of Irish nationalist politicians. Increasingly, they each referenced the intensifying militancy of the nationalist and Unionist movements in Ireland in order to legitimise their own forceful and disruptive techniques. As the 1910s progressed, both Irish and British feminists became highly sensitive to the obstructive role that Irish nationalist politics was playing in suffrage politics; negotiations over Irish Home Rule had led the Irish

Parliamentary Party, which held the balance of power in the Westminster parliament, to block the passing of the 1912 Conciliation Bill which would have enfranchised eligible women across the United Kingdom of Great Britain and Ireland (UK), for example. There is little doubt, then, that on the basis of these forged connections and because of what they saw as Irish men's undue influence in feminist politics, women of the British WSPU felt that they had every right to perform militancy in the Irish capital - whatever the objections of Irish nationalist feminists at the time.

In 1995, pioneering historian of Irish nationalist feminism, Margaret Ward, published an article on the conflicting interests of the Irish and British feminist movements. ${ }^{4}$ Her argument was that the WSPU took a pro-British stance not only on the Irish Question but also on the issue of suffragism that had dire consequences for the Irish suffrage movement. Since then, a number of other scholars have followed by examining the British and Irish movements within the same analytical framework. Louise Ryan has called for more attention to the role of British imperialism in Irish feminist affairs, commenting that the Irish movement had more in common with that in India and the Philippines than with those of other European sites who were not engaged in anti-colonial campaigns. ${ }^{5}$ More recently Ian Christopher Fletcher has outlined the similarities and differences in various British suffrage organisations' approaches to the issue of politics on the so-called Celtic fringes. ${ }^{6}$

In this paper, I expand on the work of Ward, Ryan and Fletcher by extending the argument that political expediency informed the approach taken by the British WSPU towards Irish feminist politics. I argue that it was nationalist ideology, centred on a notion of Englishness, which directed the wider political priorities of the WSPU and which had a commanding hand in shaping suffrage politics in the UK. A pervasive sense of Englishness had enabled the leaders of the WSPU, Emmeline and Christabel Pankhurst, to construct a fantasy nation drawing here on the theories of Ghassan $\mathrm{Hage}^{7}$ - that defined the UK as a multi-cultural and multi-racial entity where the more knowing, mature, rational and superior Anglo-Saxon or English core tolerated and led the more emotional, irrational, childlike and inferior Celtic peripheries. Constructing their fantasy nation in this way enabled English suffrage leaders, like the Pankhursts, to promote the idea of a UK-based transnational feminist solidarity across the 'four nations', while actively denying the legitimacy of separate nationalisms within that 'multi-national' construct. However, by repeatedly asserting that their movement 
was distinctively Irish and not simply a branch of the more dominant English campaign, Irish suffrage militants, led by staunch nationalists like Hanna Sheehy Skeffington and Margaret Cousins, worked to deny English militant suffragists' construction of the tolerant, inclusive but superior English feminist. Far from ignoring or eclipsing the importance of the national within the transnational, as English nationalist feminists had done - and while acknowledging the imbalance of power existing between suffragists in the British metropole and those in the Celtic peripheries - Irish nationalist feminists stressed that their entanglements with English militants were transnational in actuality as they crossed national boundaries that were or should have been in place and respected. Such an interpretation of the unequal status of feminists within the various colonial and imperial contexts of the United Kingdom in the early twentieth century is intended to open up discussions about the powerful role that English nationalism played in suffrage politics at a time when nearly all of the focus was on the seemingly disruptive influence of Irish nationalism.

\section{Nationalism and Transnational Feminism in the UK}

Historians of empire and those studying women's history have long had cause to embrace transnational approaches to the past; that is, studying the movements and exchanges across national and colonial borders. ${ }^{8}$ Empire by its very nature operates across multiple and dispersed sites or nations. Participants in women's movements, although often grounded in their national context, have also tended to connect with ideas and activists internationally. ${ }^{9}$ Scholars of feminist activism within a colonial or imperial paradigm have multiple reasons for examining the circulation of peoples, goods and ideas between and across national and colonial sites. Those examining the lives of colonial women have the opportunity of using transnational methodologies to challenge traditional or conservative notions of metropolitancolonial relationships by highlighting the value of ideas flowing from the so-called 'margins' into the 'centre'; and many have done so. ${ }^{10}$ Re-evaluating the flow of ideas between imperial and colonial sites is not without its challenges. Scholars of feminisms in the Americas, like Maylei Blackwell, have warned against adding to the inequalities suffered by certain groups of women by ignoring their distinctive contexts and conditions - geopolitical, colonial, racial, economic and sexual - and instead concentrating on the linkages formed by the 'Sisterhood is global' approach. ${ }^{11}$ It is this wariness of overlooking diversity and the differences of the local or the national that directs my examination of the relationship between British and Irish militant suffragists.

Transnational approaches to the study of different but connected feminisms have appropriately been applied to histories of the British Empire. The Empire connected multiple sites, nearly all of which were experiencing some form of feminist agitation in the late nineteenth century and early to mid-twentieth century while also negotiating colonial-national identities (this is certainly true for colonies like Australia, India, and Canada). However, examining the usefulness of a transnational approach to the study of women's movements also has important implications for the history of Britain's 'internal' empire, namely, the United Kingdom of Great Britain and Ireland, established with the 1800 Act of Union. ${ }^{12}$ The question of whether or not Ireland was a colonial possession or an equal and willing partner in the UK is one that is still debated within Irish historiography. ${ }^{13}$ Certainly, the late 
twentieth-century conflict, the Troubles, in Northern Ireland rendered this question a vital one given nationalist paramilitaries' insistence that they were fighting an anti-imperial war. ${ }^{14}$ At the beginning of the twentieth century, nationalist feminists - through, for example, the IWFL - undoubtedly framed their two-fold activism, gendered and national, as a monumental struggle against a dominant colonial power, thereby adding to what was an already fractured suffrage movement. ${ }^{15}$

However, the colonial dimension of the Irish situation was not accepted by the IWFL's militant sisters in England. Members of the WSPU repeatedly asserted that the UK was a well-balanced blend of 'races', namely Anglo-Saxons in the core and Celts around the peripheries. This multi-racial or multi-cultural ${ }^{16}$ nation was ruled over by one imperial parliament, operating out of the British imperial centre, in London. The WSPU recognised that the Irish had a right to be unhappy with the way in which the imperial parliament had administered Irish affairs. The British centre had unjustly used coercion in Ireland in order to subdue the discontent of the Irish population. However, that tradition of injustice could now be set to right with the establishment of a local parliament that could exercise a degree of autonomy with regards to local or regional affairs, while still being subject to the rulings of the more important imperial parliament (Home Rule). The separatist, anti-colonial and antiBritish policies of later strands of popular Irish nationalism were not to be tolerated for that was not in keeping with English nationalism which was at the centre of the WSPU's feminist ideology. (The Pankhursts, for example, prioritised nationalism over internationalism as demonstrated by their later assertion in their paper, Britannia, 'Internationalism is based upon Nationalism and without Nationalism it is impossible'. ${ }^{17}$ As Anne McClintock has clarified, feminism and nationalism are not transhistorical phenomena for they each have a history. ${ }^{18}$ Throughout the first two decades of the twentieth century, the WSPU espoused a particular blend of English nationalist feminism peculiar to its time and context that directed its interactions with Irish militant suffragists.

A substantial body of literature now exists on how feminism and nationalism variously merged and clashed within the early-twentieth-century Irish context, but relatively little has been published that extrapolates just how far those often competing ideologies meshed in the English centre. For the most part, scholarly emphasis has been on how imperialism connected to but also distinct from English nationalism - directed the reactions of many towards feminism within the British metropole; certainly the reactions of anti-suffragists. ${ }^{19}$ Numerous scholars have commented on the international dimension of English national identity; its inextricable ties to imperialism. Catherine Hall writes that Empire provided 'a frame for England itself, a way of knowing what it was to be English' ${ }^{20}$ Krishan Kumar, Shula Marks and Bernard Porter likewise assert that English nationalism centred on the idea that the English were at the head of a vast imperial network that brought civilisation, progress and modernity to far-flung corners of the globe. ${ }^{21}$ Robert Young argues, therefore, that Englishness was defined 'less as a set of internal cultural characteristics attached to a particular place, than as a transportable set of values which could be transplanted, translated and recreated anywhere on the globe'. ${ }^{22}$ Thus London was not seen simply as 'the capital of 
England, nor of Great Britain, nor even of the Empire, but of the whole Anglo-Saxon world'. ${ }^{23}$

England's 'internal' empire too was predicated on a racial hierarchy in that the 'independent, energetic, self-reliant, masculine and liberty-loving' Saxon centre ruled over the 'emotional, imaginative, feminine and gregarious' Celtic fringe. ${ }^{24}$ Here, I am drawing on racial discourses of the time that variously constructed the Celts and the Saxons as individual 'races', while also denying Celtic claims to racial status depending on what was considered to be politically expedient within a specific context and time. ${ }^{25}$ This sense of racial - and later ethnic $^{26}$ - superiority, combined with the belief that Englishness was portable and therefore cosmopolitan, served to show that the English were above the follies and the provincialism of crude nationalism. In disdaining loyalty to a purely local nationalism, and espousing a more internationally-focused Anglo-Saxon nationalism with London at the centre, the English demonstrated that they were fit to rule all ethnicities, races and interests. ${ }^{27}$ The English may have drawn on a discourse of British nationalism when dealing with divisions and diversity within its 'internal empire', the UK, but, as Ben Wellings has argued, that does not mean that a specific form of English nationalism was absent. Rather, he asserts, it tended to lie 'hidden' within British nationalism. ${ }^{28}$ It is my argument, then, that exchanges between Irish and English militant feminists served to expose the 'hidden' Englishness - directed as it was by a sense of Anglo-Saxon superiority - at the centre of British nationalistic discourse. Such an uncovering of just how influential this nationalist ideology was in shaping the feminist ideology of the WSPU helps us to understand how English militant suffragists were able to 'borrow' the politically militant strategies of Irish nationalists, for example, while denying the legitimacy of that very nationalism.

\section{Militant Connections and Disconnections}

The official bulletin of the WSPU from 1907 to 1912 was Votes for Women, which was edited by Emmeline and Frederick Pethick Lawrence until they were unceremoniously ejected from the organisation by Christabel and Emmeline Pankhurst. ${ }^{29}$ Although the Pethick Lawrences continued publishing Votes for Women as a vehicle for the concerns of militant suffragists in England, actual responsibility for voicing the demands of the WSPU passed to the newly established paper, The Suffragette, which was established and edited by Christabel Pankhurst until the war broke out. ${ }^{30}$ Reflecting its heavily inflected wartime patriotic content, The Suffragette was relaunched as Britannia in 1915. These papers captured, among other things, the growing sense of frustration and indignation felt by militant suffragists in the English centre in the early years of the 1910s. They also give us an insight into how the English militants viewed the nature of the movement which they led and, to an extent, they allow us glimpses into how suffrage militants elsewhere, particularly in Ireland, reacted to this dominant English mindset.

Votes for Women reported that there was much linking the British and Irish suffrage campaigns, especially before the war commenced, and undoubtedly there was. Irish suffragists contributed articles to Votes for Women. News on what was happening in the Irish 
campaign appeared in the pages of the English paper (under 'Ireland' and then later under 'Ireland' and 'Ulster', although this was before the country was partitioned). Irish women formed distinct sections of deputations and pageants and parades in the English centre. English suffragettes visited Ireland to rouse support for the movement (including Emmeline and Christabel Pankhurst). Irish militant suffragists were reportedly encouraged by the actions of their fellow militants in England. Certainly Margaret Cousins, one of the founders of the IWFL, had admitted that she had been inspired to form the militant Irish organisation after witnessing a WSPU meeting in Manchester. The London-based Pethick Lawrences, as editors of Votes for Women, had donated two hundred and sixty pounds for the establishment of the official organ of the IWFL, the Irish Citizen. ${ }^{31}$ The WSPU even set up branches in Ireland, although these were not always welcomed by Irish nationalist suffragists. Votes for Women repeatedly commented on the position of Irish women in terms of the Home Rule Bill being negotiated at Westminster. Irish nationalist militant feminists, including Hanna and Francis Sheehy Skeffington, although determinedly reinforcing the point that the suffrage movement in Ireland was distinct to that in England, supported the tactics of the WSPU and the rights of WSPU prisoners - whether incarcerated in England or in Ireland - especially when these prisoners were being denied political status and subject to force-feeding after hunger striking. ${ }^{32}$ Later, Irish suffragists also declared themselves vehemently opposed to the renowned Prisoners (Temporary Discharge for Health) Act of 1913, more commonly known as the Cat and Mouse Act, which allowed for hunger-striking suffragette prisoners to be continually released and then re-arrested once they had recovered their health. ${ }^{33}$

However, the view of Irish nationalist feminists that the Irish and British suffrage campaigns were separate, although connected, was irrevocably violated in 1912 when English militants carried out the previously-mentioned hatchet and theatre fire activities in Ireland. That year the WSPU also stated that it was coming out in opposition to Home Rule politicians in retaliation at the role that those Irish politicians had played in the defeat of the Conciliation Bill that would have seen women across the UK enfranchised. The WSPU's decision to abandon militancy in 1914 in favour of working towards the imperial war effort confirmed the extent of the chasm existing between the nationalist militants in Ireland and the nationalist militants in England. ${ }^{34}$ The decision made by English leaders to withdraw their movement from the north of Ireland further angered the IWFL because it had the effect of devastating the suffrage campaign there - even before Unionists and nationalists knew what was going to happen to their respective communities as they armed in anticipation of civil war. The WSPU and the IWFL were allied by the fact that they both fervently believed in the universalised notion of gender equality and were campaigning for a vote for the same parliament. But, their respective reactions to imperial and colonial politics and their entrenched and deepening senses of Irish and English nationalisms prevented any greater alliance, whether English suffragettes, in particular, acknowledged this state of affairs or not.

One distinctive element that unequivocally connected the WSPU and the IWFL, whatever their differences, was their collective dedication to conducting a militant form of suffragism, where militancy embraced both politically aggressive strategies and physically violent tactics. Militancy also connected the two national sites (in IWFL terms) or regional sites (according 
to the WSPU) in other ways. The WSPU declared that, since its inauguration, Irish forms of militancy had inspired and directed its political efforts. Votes for Women made it clear that the WSPU had modelled many of its politically militant tactics on strategies introduced into British political culture by Charles Stewart Parnell and the Irish Party in 1885 (who had worked to oppose the election of Liberal Party candidates who were antithetical to Irish Home Rule). In 1910, the British paper commented that the 'glimpse into the working of the political machine which the Irish parallel affords is of great practical value to Suffragists of to-day'. ${ }^{35}$ The paper likewise cited the militant tactics of the Ladies' Land League of the Parnell era, managed by the Irish Party leader's sister, Anna Parnell, as evidence not only of women's ability to be politically active more generally, but also of the debt of gratitude that Irish men owed their Irish sisters more specifically. This was a debt that could be honoured, Votes for Women said, through granting Irish women the franchise via amendments to the Home Rule Bill. ${ }^{36}$

The WSPU also declared that it drew inspiration from the physically violent tactics that men increasingly employed in the highly volatile Irish political sphere. Irish men - nationalist and Unionist - were fast proving to English militant suffragists that the British government was responsive to acts of physical violence. English suffragettes worked to expose the gendered double-standards governing both British and Irish politics; a standard that saw men's militancy accepted and women's rejected and condemned. Nearing the end of 1910, Votes for Women declared that if there were any people left who condemned women for 'taking vigorous action to win their liberty', they should look to male politicians who were threatening outright rebellion for a similar cause. For example, in an article entitled 'Ulster Will Fight', the paper pointed out that Unionist men had just announced that they were going to 'take forcible measures' if Home Rule was to become a reality on the island. ${ }^{37}$ Two years later, in 1912, the paper referenced Irish political militancy again, noting: 'Militant Suffragists have not failed to notice that both Home Rulers and Unionists admit rebellion to be virtuous, provided there exist oppression and injustice which can be removed in no other way'. Declaring the rebellion of militant suffragists to be one of the 'most righteous the world has ever seen', Votes for Women asserted that militant feminists were in agreement with such endorsements of force. However, while drawing attention to men's validations of political violence, the paper also worked to remind readers that women had not waited for men's sanction before launching their physically-destructive feminist campaign. ${ }^{38}$

Suffragette indignation over the continuing double standard with regard to gendered forms of political violence only intensified. Public outrage in Ireland in response to the 1912 hatchetthrowing and theatre-burning incidences particularly angered the WSPU and motivated it to counter opposition to women's violence with a heated exposition on that of Irish men. 'No concession has ever been made to Ireland', Votes for Women declared, 'except in response to force - either Parliamentary force or physical force.' 39 This was true of the entire modern history of the island. For example, nineteenth-century Fenian violence, although causing death - including the death of a policeman in Manchester in 1867 and the executions of those responsible, deaths that marked Emmeline Pankhurst's memory - resulted in Gladstone-led reform, such as the Disestablishment of the Irish Church and the passage of the Irish Land 
Act of 1870. The no-rent campaign 'and the attendant outrages' of Parnell's Land League compelled the passage of the Land Act of 1881, Votes for Women declared. The Dublin Phoenix Park murders - namely, the assassination of the British Chief Secretary of Ireland and his under-secretary - although deplored by both Parnell and the English public, did not prevent the inclusion of Ireland in the extension of the electorate for the British House of Commons through the Reform Bill of 1884. All in all, the paper asserted, force has enabled victory to Irish politicians. English militant feminists wanted to know, then, "whether or no Irish history gives warrant for violent and lawless action on the part of the politically disinherited' ${ }^{40}$ The sentencing of the WSPU prisoners in Ireland - those who had perpetrated the hatchet-throwing and theatre-burning incidences - to five years penal servitude while Irish male 'treason-mongers who have votes', and who continue to incite violence, go free incensed English militants. ${ }^{41}$

By 1913, when the use of violence for nationalist and Unionist ends radically intensified with the arming of the Ulster Volunteer Force and then the various nationalist forces, Votes for Women affirmed once again that the British government capitulated in the face of male violence, so why not women's? ${ }^{42}$ The implication was, of course, that Irish political tactics, even if they amounted to treachery, and the British government's concessions because of those tactics, served to confirm that citizens who deserved a direct say in the affairs of the UK could legitimately use force to campaign for that right. The WSPU adopted a universalised approach to the employment of militancy within the sphere of UK politics. It saw no difference between using militancy to bolster Irish moves for greater representation in a British parliament and a gendered campaign for the same aim. But, as events during the war were to reveal, the British feminist organisation certainly did not endorse the use of violence for anti-colonial activism within that same UK and against that same British government.

The WSPU may have endorsed the example set by Irish men who used violence as a political weapon, but it warned militant feminists - on both sides of the Irish Sea - against getting involved in Irish nationalist politics to the detriment of feminist politics. Votes for Women was adamant that English militant feminists should not take a side on the Irish Question. In the years immediately preceding the war, it also attempted to command Irish militant feminists to not take sides on the Irish Question in the same way that it had previously instructed English militants not to do so. In 1913, Irish women were told that their duty was clear: they were to prioritise the woman suffrage issue over questions of national politics. Nationalist and Unionist politicians in Ireland were fast committing themselves to antifeminist politics, the paper asserted. The blame for 'this disgraceful state of affairs' lay with Irish women themselves who had been guilty of placing the claims of their parties before those of their sex. ${ }^{43}$ In early 1914, the paper strengthened its instruction to Irish feminists to support gender politics over those of the Irish nation. It published a front page cartoon depicting an Irish woman staunchly rejecting nationalism and Unionism in order to prioritise gaining her own freedom as a woman. ${ }^{44}$ This was not the first time that English militants had claimed that they had led Irish women towards the right suffrage pathway, and more specifically, that they had led Irish women on the pathway to feminist militancy. In 1910, on 
the occasion of Christabel Pankhurst's visit to Ireland, Votes for Women reported that Pankhurst had said that she was there representing the militant suffragettes of England so that 'she might be able to hand on to the Irishwomen the flaming torch which they would carry through the length and breadth of Ireland' ${ }^{45}$ Later that year, Votes for Women reported that Irish women had started their own militant campaign. In doing so, the paper made it clear that Irish women were 'following the example of their sisters across the sea'. ${ }^{46}$

Not all English commentators found this direction in Irish suffrage politics to be a positive one, of course. The British Anti-Suffrage Review, organ of the National League for Opposing Woman Suffrage, certainly did not see Irish feminist militancy as being beneficial to Irish or to British society. But neither did it refute the claim that British women led the way. By introducing the wanton tactics of the WSPU into Ireland - window-breaking but then moving on to the 'even more dastardly' acts of hatchet-throwing and arson - English militants had 'brought discredit upon a country where Suffragists had up to this time remained uninfected by the hysteria of their kind in England'. Irish suffragists might not have perpetrated these actual crimes, the Anti-Suffrage Review admitted, but neither had they repudiated them. Therefore, they were implicitly guilty of tarnishing Irish society (where perfectly innocent women could no longer walk down the streets without fear of being attacked as perceived suffragettes). They were also guilty of further embittering and dividing Irish national politics (for Irish feminists could no longer hope to secure the endorsement of now alienated the Irish Parliamentary Party). The overall message of the article was that Irish women had naively followed in the footsteps of their more knowing radical English sisters. In doing so, they had, thoughtlessly, thrown their tumultuous country into further chaos. ${ }^{47}$

Yet, and seemingly at odds with their declarations that they had led Irish women to militancy, English suffragettes also fed into an increasingly popular discourse that claimed that the Irish were not only renowned for militancy but that they were naturally a martial 'race'. By 1911, in recognition of the growing militant suffrage movement there, Christabel Pankhurst affirmed that the 'women of Ireland come of a fighting race' ${ }^{48}$ Unlike English women, Irish women could work to secure enfranchisement under a Home Rule Bill and they were employing militant tactics in the attempt to do so. Therefore, they served as an inspiration for all suffragists, because if they used militant tactics to successfully secure the vote in a local parliament, then they would set a precedence for women across the UK to also win the franchise. ${ }^{49}$ The idea that they were members of a naturally militant 'race' was one that the IWFL also increasingly espoused. In 1913, for example, Votes for Women cited the 1912 IWFL Annual Report when it recorded that the militant IWFL was the largest and most active suffrage society operating in Ireland. To demonstrate its assertion about the martial nature of the Irish, the English paper quoted the IWFL as saying that the stature of its organisation demonstrated that 'militant societies are native to our soil, and that Irish men and women respond most naturally to militant appeal' ${ }^{50}$

In 1915, the IWFL's Irish Citizen ${ }^{51}$ published a speech delivered by renowned Irish nationalist, feminist and socialist militant, Constance Markievicz, which declared Irish 
women to be part of a proud race of warrior women. Markievicz had been advocating this line of thinking for a number of years. ${ }^{52}$ She had presented lectures on the topic and had published her thoughts in women's periodicals (particularly the nationalist feminist paper, Bean na hEireann (Woman of Ireland) which preceded the Irish Citizen running as it did from 1908 to 1911). ${ }^{53}$ She also led by example, being the only women to be sentenced to be executed for her military role in the failed 1916 nationalist uprising in Dublin, a sentence that was commuted to life imprisonment because of her sex. ${ }^{54}$ Markievicz put particular pressure on the women of Ireland to take up this mantle of militant Irish femininity. 'I have never heard in the early history of any country so many stories of great fighting women as I read in the history of Ireland', she declared. Here she was referring to the stories of women (mythological and real) like Queen Maeve, goddess Macha, Ireland's pirate queen Granuaile, and many others. ${ }^{55}$ Fighting was in the Irish woman's blood, Markievicz asserted. 'Ancient Ireland bred warrior women, and women played a heroic part in those days'. 56 Despite being published in a suffrage paper, Markievicz's main aim was to cajole Irish women into arming in support of nationalist politics - which Irish women were to do in substantial numbers for the various nationalist and Unionist militant campaigns from 1916 until 1923. ${ }^{57}$ To increase the number of women inspired to take up arms for the nationalist cause, she issued the provocative statement that, today, the spirit of the warrior women of old was only alive in suffragettes and Trade Union women. ${ }^{58}$

Markievicz was not alone in claiming this distinct heritage for the women of Ireland. Hanna Sheehy Skeffington and others repeatedly asserted that there was an ancient Irish tradition of gender equality: political, social, militant. The men of Ireland - who did not support this equality - had simply lost their way of late. It was up to the women of Ireland to help them get back in touch with this sense of ancient and equal nationalism. ${ }^{59}$ Margaret Cousins used the onset of the Great War to issue the call: 'One man, one gun; one woman, one gun.' As Cousins pointed out, women were already arming in Ireland in anticipation of civil strife between nationalists and Unionists - as evidenced by women's involvement with the Unionist Ulster Volunteer Force and the nationalist Cumman na mBan, the Women's Council, or women's auxiliary of the Irish Volunteers, and later the Irish Republican Army and yet men were still applying the dictum that women were not and should not be militant, even in Ireland. ${ }^{60}$

As in England, militant suffragists in Ireland legitimised their militancy on the grounds that Irish men had long used this national heritage of militancy to achieve their aims and these tactics had proved effective. Like Votes for Women, the Irish Citizen stated that the actions of Irish men and the reactions of English leaders like Gladstone had taught Irish women the efficacy of violence. ${ }^{61}$ In a country that was gearing up for civil war, feminist activists were continually confronted by an increasing reliance on brute force over peaceful constitutionalism. The Irish Citizen painted a picture of one such scene. Hanna Sheehy Skeffington and her fellow suffragist, Margaret Connery, were arrested in October 1914 for attempting to address a crowd close to where the British prime minister, Herbert Asquith, was speaking. Nearby, male socialist activists, Jim Larkin, James Connelly and P.T. Daly, led a meeting, protected by a large body of men from the Irish Citizen Army with bayonets and 
rifles which they apparently discharged into the air from time to time. While authorities felt it incumbent to arrest and detain two unarmed female protestors, they made no attempt to interfere with gun-wielding men. The Irish Citizen declared that scenes such as these were strikingly demonstrative of the value of men's use of political force. ${ }^{62}$

There were substantial differences, however, between English suffragettes' use of Irish men's militancy to legitimise their feminist activism and that of Irish militant suffragists. English militants expressed their indignation on the grounds that while the British government was capitulating to men over in Ireland because of their constant threat of violence, that same government was torturing women - on its own soil - who were performing feats of a less dangerous nature for a cause that was equally or even more righteous than that of Irish nationalism. Irish nationalist feminists also expressed indignation that Irish men's violence was treated with much less severity than Irish or English women's. Yet, Irish militants differed from their English counterparts in that they also positioned themselves alongside militant nationalist Irish men, as members of a distinctly martial 'race'. They used Irish men's and women's shared history of violent activism to claim a special nationalist relationship with militancy - for both sexes. ${ }^{63}$ By the beginning of the war, Irish women were using the fact of their militant tactics less to affirm their bond with their English sisters, and more to connect more closely with Irish nationalism.

\section{Disconnections: Intensifying Nationalisms on both Sides of the Irish Sea}

By increasingly using their militancy to confirm their nationalist values, the IWFL was intensifying a nationalist ethos that it had determinedly espoused since its establishment. In November 1910, Votes for Women published a letter from Hanna's husband, Francis Sheehy Skeffington, which declared that the IWFL was in complete sympathy with the militant tactics of English suffragettes. That one of the IWFL's first acts was to send a vote of solidarity to militants in England demonstrated this. However, he was also at pains to alert readers of the English paper that the IWFL was 'an independent organisation, working on Irish lines and with special reference to Irish conditions' ${ }^{64}$ It was no mere off-shoot or follower of the WSPU. (Indeed, Votes for Women was to later register that the IWFL refused to let anyone other than Irishwomen join their group. ${ }^{65}$ ) Sheehy Skeffington admitted that English suffragists were the first to adopt militant tactics. He said there were two reasons for this. In the first place, Irish feminists had been too apathetic. Until now, they had been content to share the spoils once English women had won the franchise. Secondly, it had been difficult for Irish feminists to be active in the militant suffrage campaign because of the constitutional arrangement existing between Ireland and England. Irish politicians sat in an English-based parliament. The Cabinet Ministers heckled by the WSPU rarely travelled to Ireland, preferring to stay in England, the centre of power. However, once Irish feminists realised that they were not necessarily going to be included in any extension of the franchise to England, they were prompted to action. ${ }^{66}$ The WSPU may have adopted militancy first but, Sheehy Skeffington averred, Irish suffrage leaders 'had always contemplated the adoption of militant tactics by Irishwomen themselves'. It was simply that opportunities were less forthcoming than in the British centre. ${ }^{67}$ 
The IWFL were galled when the WSPU abandoned its militant campaign in 1914 in favour of aiding the war effort. The WSPU's decision to do so provoked some heated exchanges in the Irish Citizen. On a number of occasions, correspondents wrote to the paper in support of Christabel Pankhurst's rousing wartime British patriotism revealed through her pamphlet, 'The War'. These writers called on Irish suffragists to remember that there were different pressures on English women to support the war effort than on their Irish sisters. ${ }^{68}$ They also attempted to invoke the memory of the bonds existing between Irish militants and their English sisters. As one contributor put it, Irish feminists owed English militants a debt of loyalty and gratitude for the help they gave in developing feminist militancy in Ireland: "why should the Irish paper be the one to condemn those who came to Ireland and helped in militant societies more than once? ${ }^{69}$ Without addressing the militancy issue, the editors of the Irish Citizen declared that the fact that the WSPU had failed to prioritise feminist activism over male militarism was unforgiveable. To support its critique of the patriotic English suffragists, the paper contended that even Pankhurst's followers in Great Britain were aware that their feminist leaders had 'abandoned their principles in the hour of crisis' ${ }^{70}$

Of equally pressing concern for the editors of the Irish periodical was the lack of regard that the WSPU leaders had shown and were continuing to show for Irish politics. Here, at the outset of the war, the hatchet and theatre incidences of 1912 were raised again and this time they were more stridently criticised. Back in September 1912, the Irish Citizen had published an article that criticised the WSPU for interfering too much in Irish suffrage affairs. 'Many will regret', the article ran, 'that the campaign for woman suffrage in Ireland was not left entirely in the hands of the Irish suffrage societies, which are sufficiently numerous and sufficiently varied in their appeal'. ${ }^{71}$ The Irish Citizen expressed solidarity with British militants' concerns over the fate of the WSPU prisoners who had perpetrated the acts, nevertheless, the paper went on to reassert the separateness of the English and Irish campaigns: 'We believe, however, that the rousing of the Irish people on this matter had best be left to Irish women, who understand the psychology of their countrymen as the ablest English advocate never can. ${ }^{72}$ In 1914, the IWFL paper redoubled its efforts to point out that Christabel Pankhurst, in particular, was not a leader of the Irish movement, a fact that some readers seemed apt to forget. ${ }^{73}$ More than this, the editors pointed out, as an English leader, Pankhurst had 'notoriously failed...to appreciate or take into account the special circumstances of the Irish movement'. In response to one correspondent's directive that an Irish suffrage paper should not criticise the English feminist's act of prioritising the war over militant feminism, the article continued by declaring that it was difficult to ascertain on what grounds 'an Irish Suffrage paper should be obliged to refrain from publishing criticisms of her public action'. ${ }^{74}$ The following week, the Irish Citizen responded to the accusation that Ireland did not understand England's need to go to war to defend the Empire - an empire to which loyal suffragists were sincerely devoted - by reiterating its point about English disregard for Irish exceptionalism:

With regard to our opposition to the W.S.P.U. invasion of Ireland, that is based on the principle that Ireland is not England. The Irish Citizen has always recognised the existence of the Irish Sea. ${ }^{75}$ 
By that stage, and certainly to the Irish Citizen's editors, the growing gap between what might once have been cautiously perceived as a connected, though still separate and diverse sisterhood now seemed unbridgeable.

The same erosion of what was once certainly thought of as a feminist sisterhood by English militant suffragists was taking place on the other side of the Irish Sea. As with Irish nationalist suffragists, an opposing sense of nationalism was at the heart of the decay (although Irish suffragists also had the added grievance that English suffragettes had effectively abandoned the militant campaign). ${ }^{76}$ Suffragette enthusiasm for feminist militancy had been transformed and channelled into a passionate support for male militarism (although, to be fair, the WSPU had always promoted male militancy if not exactly militarism, even if only to legitimise their own use of force). For the duration of the war and in response to intensifying calls by Irish nationalists through Sinn Féin for complete separation from the UK and the British Empire - the Pankhurst paper, Britannia, denied the anti-colonialist aspirations of Irish nationalist feminists by claiming that Ireland was an intrinsically essential part of the multiracial and multicultural entity, the UK. 'Great Britain', Christabel Pankhurst announced in 1917, 'is a wonderful balance of temperaments, a wonderful blend of character and of race', so that to disturb that balance and blend would be an absolute 'calamity'. ${ }^{77}$ Pankhurst said that she spoke as part Celt which increased her appreciation of the matter. She then referred to the contempt for the Irish held by some, including the German-born scholar of Celtic languages, Professor Kuno Meyer (whom she referred to as 'that infamous spy' because he delivered a pro-German speech while in the USA during the war). She quoted Meyer as saying: 'I regard the Irish as an ill-balanced, emotional race, unfitted for self-government. I look upon them precisely as we Germans look upon the Poles - as a people only fit for poetry, rhetoric, and sedition.' While assuring her audience that the English certainly did not look on the Irish as a people fit only for sedition, Pankhurst nevertheless went on to endorse Meyer's view of the Celt as emotional. This emotionalism was not unwelcome, however. On the contrary, Pankhurst claimed to speak for the British metropole when she said: 'We look upon their romanticism as something which is necessary in this world.' 78

Through Britannia, Pankhurst went on to clarify that there were more strategic reasons other than temperamental balance - for wanting to keep hold of the Irish element of the UK. Politically, England needed 'Irish political co-operation at Westminster'; needed 'the Irish leaven in her political affairs'. ${ }^{79}$ However, not unexpectedly given the war with Germany and Ireland's strategic position as a buffer to the Atlantic, England also needed Ireland's loyalty and union to ensure the security of the entire British Isles, and for the protection of England as the centre of both the UK and the Empire. To Pankhurst, the worst of it was that Irish nationalists also did not realise how vulnerable the Irish were. They were guilty of naively demanding their autonomy thereby leaving themselves open to invasion from the far superior, worldly and calculating Germans. 'Ireland is an Ireland which will fall victim to Germany within a day', Britannia asserted, for it cannot defend itself. 'What we say as ordinary British people', the paper continued, 'is that we do not want and we will not have Germany established in Ireland'. ${ }^{80}$ Those leading Ireland on this seditious and ill-advised 
route did not know the 'real Ireland', which, by implication, Pankhurst did. They did 'not care for or appreciate the real Ireland and what the real Ireland can be'. Returning to the WSPU's earlier conviction that Britain had mismanaged Irish affairs, hence the militant organisation's support for Home Rule, though not independence, Pankhurst claimed that Ireland's 'real grievance' was simply that 'she has never been understood, and that our men have ridden roughshod over her sentiment and her idealism'. Now was the time for the English to turn their minds to the Irish Question and repair the damage inflicted by unthinking English rulers on a delicate and fragile psyche, before the union disintegrates. Such a disintegration would surely bring calamity upon the entire civilised world; a civilised world led by the English. ${ }^{81}$ (Only the previous week, Britannia had declared that an Irish republic would mark 'the end of England as a Great Power, and shatter the British Empire at a blow' ${ }^{82}$ ) Pankhurst concluded that if only the women of England had been given the political power to tackle the Irish Question, they 'would have got on with the Irish people in a way that the men have never been able to do'. ${ }^{83}$ Here she was guilty of ignoring the fact that Irish militant feminists had accused English women of doing exactly what Pankhurst accused English men of doing, namely riding roughshod over their Irish counterpart's sentiments and ideals.

The war had laid bare English militant feminists' construction of a fantasy nation - the UK where the more knowing, bountiful and benevolent, if sometimes waylaid, English or AngloSaxon centre ruled over a more emotional, almost childlike, and certainly sometimes disruptive Celtic periphery. Ever evocative of Anne McClintock's trope of the family ${ }^{84}$ namely, the idea of the nation as a family with all the hierarchies that family structure implies - militant feminists in the imperial centre strived to create a suffrage movement that recognised English activists as the superior and core members (the imperial parliament for which everyone was striving to secure a vote was, after all, located in that national centre). These core members' Englishness and proximity to the centre of power allowed them to claim, in the words of Ghassan Hage, 'a dominant form of governmental belonging'. ${ }^{85}$ The pages of feminist papers like Votes for Women, The Suffragette and Britannia operated as fantasy spaces in which women at the centre were constructed as superior (despite being not being enfranchised), with those in the margins tolerated, included. As Britannia elucidated, the Irish 'enriched' the multiracial or multicultural collective that was the UK. ${ }^{86}$ Their emotional romanticism added to a 'nation' that was inevitably directed by the rational attributes of those at its Anglo-Saxon centre. In line with Hage's theories about the limits of tolerance, as soon as the Irish decided en masse to advocate for complete separation from the nation - real and imaginative - that is to say when the ethnic or racial other (again drawing on popular racial discourses of the time) appeared to reveal a will of its own, the fantasy of 'a neatly positioned otherness constituting the national order' ended. ${ }^{87}$ By ignoring Irish militant feminists' calls for recognition of their national distinctiveness, English suffragists perpetuated the unequal relationship of power existing between the English metropole and Irish margin. However, by refusing to allow English feminists to define Irish nationalist feminist identity, Irish nationalist suffragists called into question English feminist superiority and their fantasies of national inclusiveness. 


\section{Conclusion}

Returning to Maylei Blackwell's caution earlier in this article, emphasising transnational connections - going with the 'Sisterhood is global' approach - runs the risk of overlooking the differences of the local and eliding existing inequalities, thereby confirming the continuity of those inequalities. By failing to acknowledge their position of privilege but using that status to ignore their fellow feminist militants' claims to national distinctiveness and autonomy, early twentieth-century English feminist militants revealed their allegiance to a strident form of English nationalism. English nationalism allowed for the women of the WSPU to promote the idea of a UK-based transnational feminist solidarity across the 'four nations', while actively denying the legitimacy of separate nationalisms within that construct. That nationalism also accounts for what many have characterised as the organisation's sudden and surprising turn away from suffrage politics and towards war work in 1914. The WSPU's 'turn' should have come as no surprise to Irish nationalist suffragists who had been continually confronted with English feminists' latent English nationalism in the pre-war years. In those years, a sense of English superiority had always been present in the writings and speeches of the WSPU - as exemplified by the organisation's attitude towards the Irish Question - despite Irish feminists' rejection of such a hierarchy. Therefore, far from confirming the much repeated story promulgated by the WSPU that Irish nationalism performed as the disruptive influence in otherwise rational British politics, I have used this article to argue that exchanges between Irish and British militant feminists exposed the powerful, even dominating hand that English nationalism had in directing suffrage politics in the UK.

\footnotetext{
${ }^{1}$ Suffragette is the term coined for members of the militant WSPU. Members of the militant body, the IWFL, also sometimes used the word when referring to themselves. However, I tend to use suffragette sparingly and instead employ militant suffragist with a national prefix in this article in order to more clearly delineate between Irish and British militants.

${ }^{2}$ Hannam, Auchterlonie and Holden, International Encyclopedia of Women's Suffrage, 325. For a discussion of the complicated and contentious relationship between the Independent Labour Party and women's suffragists, particularly the WSPU, see Purvis, Emmeline Pankhurst, especially 65-78 and 79-95.

${ }^{3}$ The first group of Irish women to be imprisoned in Ireland for their militancy consisted of eight women: Hanna Sheehy Skeffington, Margaret Murphy, Jane Murphy, Marguerite Palmer, Marjorie Hasler, Kathleen Houston, Maud Lloyd, and Hilda Webb. They were arrested in Dublin in June 1912 for throwing stones through the windows of government offices. However, prior to this, in 1910 and then again in 1911, Irish women, including IWFL co-founder, Margaret Cousins, were imprisoned in England for participating in protests organised by the WSPU. See Murphy, Political Imprisonment and the Irish, 14.

${ }^{4}$ Ward, 'Conflicting Interests', 127-147.

${ }^{5}$ Ryan, 'Traditions and Double Moral Standards', 490; and, Ryan, 'A Question of Loyalty', 21-32.

${ }^{6}$ See Fletcher, 'Women of the Nations, Unite!' 103-120. Elizabeth Crawford has published a reference guide that looks at the Irish suffrage movement as one of the regional campaigns within the larger British and Irish movement. I am not inclined to view the Irish movement as simply a regional branch of the overall combined British and Irish campaign, as I argue in this paper. Crawford has also explored the differences between the British and Irish points of view in an unpublished conference paper available on her Blog site. See Crawford, 'Suffrage Stories'. Also see Kelly, 'Irish Suffragettes'.

${ }^{7}$ Hage, White Nation.

${ }^{8}$ Here I am applying an understanding of transnationalism as the movement of people, institutions and ideas across and through national boundaries. See Iriye, 'Transnational History', 212; Tyrrell, 'Comparative and transnational history', 49; and, Curthoys and Lake, 'Introduction', 6-20.

${ }^{9}$ In the 1990s, a number of important works examined the international dimension of women's activism and interrogated shared and diverse understandings of feminism within that international context. See, for example:
} 
Tyrrell, Woman's World; Sinha, Guy and Woollacott, 'Feminism and Internationalism', 345-600; and, Rupp and Taylor, 'Forging Feminist Identity', 363-386.

${ }^{10}$ See, for example, Paisley, 'Introduction', 272.

${ }^{11}$ For example, see Blackwell, Briggs and Chiu, 'Transnational Feminisms', 4-6. Earlier scholars of 'Third World' feminisms also cautioned against overlooking difference in feminist historiography. See, for example, Mohanty, 'Under Western Eyes', 333-358. While others stressed the complexities of Western women's involvement in imperial and colonial sites. See Chaudhuri and Strobel, Western Women and Imperialism'.

${ }^{12}$ Krishan Kumar refers to the UK as England's internal empire. See Kumar, "Nation and Empire', 575-608.

${ }^{13}$ For example, see Gibney, 'Early Modern Ireland', 172-182.

${ }^{14}$ For a detailed discussion of whether or not the Northern Irish conflict was an anti-colonial conflict, see Miller, 'Colonialism and Academic Representations of the Troubles', 3-39.

${ }^{15}$ For general histories of the Irish suffrage campaign, see Rosemary Cullen Owen, Smashing Times, Attic Press, Dublin, 1984; and, Murphy, The Women's Suffrage Movement. In 2018, Margaret Ward's and Louise Ryan's 2007 edited collection, Irish Women and the Vote, was revised and republished to coincide with the centenary anniversary of the granting of limited woman suffrage in Britain and Ireland. For more nuanced discussions of the competing national and gendered loyalties, see: the previously mentioned 'Conflicting Interests' article by Ward. See also: Murphy, 'Suffragists and Nationalism', 1009-1015; Ryan, 'Traditions and Double Moral Standards', 490; and, Ryan, 'A Question of Loyalty', 21-32. In Women of the Dáil, 12, Jason Knirck argues that decisions about whether to pursue nationalist or feminist goals first was not about the ultimate desirability of one over the other but about 'timing and priority'. For a detailed discussion on the differences of women's nationalism in Ireland, see Ward, Unmanageable Revolutionaries; and, more recently, Pašeta, Irish Nationalist Women.

${ }^{16}$ I am drawing on terminology that is in current usage - 'multi-cultural' and 'multi-racial' - to clarify the WSPU's vision of the UK. It declared that the UK was a 'blend of races' and argued that it was the different cultural characteristics of the Anglo-Saxons, on the one hand, and the Celts, on the other, that gave it its distinctive balance in temperament. This is discussed in greater detail later in the article.

17 'Lack of Patriotism a Disease!', Britannia 5, no. 27 (14 April 1916), 165 (Listed Nineteenth Century Collections Online (Gale) as The Suffragette).

${ }^{18}$ McClintock, 'Family Feuds', 77.

${ }^{19}$ For example, for a discussion of how fear of imperial decline coloured much anti-suffrage commentary, see Crozier-De Rosa, 'Marie Corelli's British New Women', 416-429.

${ }^{20}$ Hall, 'Going a-Trolloping', 180.

${ }^{21}$ Kumar, 'Nation and Empire', 575 and 591; Marks, 'History, the Nation and Empire', 115-117; and, Porter, The Absent-Minded Imperialists, 243-244.

${ }^{22}$ Young, The Idea of English Ethnicity, 232.

${ }^{23}$ Young, The Idea of English Ethnicity, 6.

${ }^{24}$ See Young, The Idea of English Ethnicity, 45.

${ }^{25}$ Luke Gibbon traces some of the debates over 'race' in Irish-British exchanges and argues that, whatever scholars now think of such claims to racial status, many forms of Irish cultural nationalism were predicated on notions of race and that such claims to racial distinctiveness prevented a substantial proportion of the Irish community from becoming citizens of the Empire. See Gibbons, 'Race Against Time', 207-223.

${ }^{26}$ Young argues that ethnicity came to replace race as a category of classification in the mid-twentieth century, following the atrocities of the Nazi regime. See Young, The Idea of English Ethnicity, 232.

${ }^{27}$ Young, The Idea of English Ethnicity, 237-8.

${ }^{28}$ Wellings, 'Empire-nation', 95-109.

${ }^{29}$ Quoted in DiCenzo, Feminist Media History, 1.

${ }^{30}$ Purvis, Emmeline Pankhurst, 195.

${ }^{31}$ See, among other histories, Murphy, The Women's Suffrage Movement, 76; and, Crawford, The Women's Movement, 261.

${ }^{32}$ For articles published in Votes for Women demonstrating Irish support for the WSPU prisoners in Ireland and another by Hanna Sheehy Skeffington on being imprisoned for militancy, see 'The Suffragists in Mountjoy Prison, Dublin', Votes for Women 5, no. 233 (23 August 1912), 765. For an account of the discussions leading to the decision to support the moves for political status of the imprisoned English militants and the divisions this caused within the IWFL, see Murphy, Political Imprisonment and the Irish, 11-33.

${ }^{33}$ See 'Intermittent Torture of Suffragists', Votes for Women 6, no. 278 (4 July 1913), 590.

${ }^{34}$ For a discussion of how Irish nationalist feminists accused English militants of being dishonourable feminists during the war, see the chapter on 'War and the Dishonourable British Feminist' in Crozier-De Rosa, Shame and the Anti-Feminist Backlash, 131-164.

35 'Holding the Balance of Power', Votes for Women 3, no. 96 (7 January 1910), 233.

${ }^{36}$ See, for example, ‘An Irishwoman's View', Votes for Women 3, no. 102 (18 February 1910), 32. 
37 'Ulster Will Fight', Votes for Women 4, no. 143 (2 December 1910), 138.

38 'The Right of Rebellion', Votes for Women 5, no. 216 (26 April 1912), 470. One month later, Votes for Women reported that both Mr Birrell, Chief Secretary for Ireland, and renowned Ulster Unionist, Sir Edward Carson, had asserted that Unionists would fight for their civil liberties and that the English public would endorse that fight. See 'Inciting to Militancy', Votes for Women 5, no. 219 (17 May 1912), 523.

39 'Violent and Lawless Action', Votes for Women 5, no. 229 (26 July 1912), 700.

40 'Violent and Lawless Action', Votes for Women 5, no. 229 (26 July 1912), 700.

41 'The Women's Fight in Ireland', Votes for Women 5, no. 239 (4 October 1912), 851.

42 'Yielding to Force', Votes for Women 7, no. 314 (13 March 1914), 364. Votes for Women expressed outrage in 1914 when WSPU offices were raided but not those of Unionist leader, Carson, despite evidence that he was inciting treason. See 'Belfast Offices Raided', Votes for Women 7, no. 318 (10 April 1914), 424; and, 'The Outlook', Votes for Women 7, no. 321 (1 May 1914), 465.

43 'The Betrayal of Ireland', Votes for Women 6, no. 259 (21 February1913), 298.

44 'Tim Healy's Zoo', Votes for Women 7, no. 314 (13 March 1914), 357.

45 'Handing on the Torch', Votes for Women 3, no. 106 (18 March 1910), 387. Irish suffragists had also invited Emmeline Pankhurst to visit the island which she did in 1910 and again in 1911. See accounts of her visit: 'Mrs. Pankhurst in Ireland', Votes for Women 4, no. 135 (7 October 1910), 4; 'Mrs. Pankhurst in Ireland', Votes for Women 4, no. 138 (28 October 1910), 53; and, 'Mrs. Pankhurst in Ireland', Votes for Women 4, no. 162 (14 April 1911), 463.

46 'Mr. Birrell to Receive a Deputation', Votes for Women 4, no. 138 (28 October 1910), 53.

47 'Dublin Notes: Dublin Militants', Anti-Suffrage Review, no. 46 (August 1912), 188. For an extended discussion of the perceived effects of feminist militancy on Irish codes of chivalry, see Crozier-De Rosa, Shame and the Anti-Feminist Backlash, 204-210.

48 'Woman Suffragists and Irish Home Rule', Votes for Women 45, no. 189 (20 October 1911), 41.

49 'Woman Suffragists and Irish Home Rule', Votes for Women 45, no. 189 (20 October 1911), 41.

50 'Irish News', Votes for Women 6, no. 273 (30 May 1913), 514.

51 The Irish Citizen, established in 1912 by Margaret and James Cousins and Hanna and Francis Sheehy

Skeffington, avowed that it was a paper whose intentions were to represent Irish suffragism, as distinct from the campaign in England. Within months of its establishment, the paper reported that it was selling perhaps 3,000 copies per week with a readership of over 10,000. See Murphy, The Women's Suffrage Movement, 34.

52 In 1909, for example, she issued a call of arms to Irish women: arm yourselves to defend your country and do not trust the 'problematic chivalry' of men to protect you and your country. See 'Editorial Notes', Bean na hEireann 1, no. 9 (July 1909), 8.

${ }^{53}$ The Bean na hEireann was the organ of Inghinidhe na hEireann (Daughters of Ireland), a radical nationalist, pro-militant women's group that was to later merge with Cumman na mBan, the women's wing of the Irish Republican Army. For recent works examining the women's press in Ireland around this time, see: Crozier-De Rosa, 'Shame and Anti-Feminist Politics', 346-359; Innes, 'A voice in directing the affairs of Ireland', 146-158; Louise Ryan, 'The Irish Citizen, 1912-1920', 105-111; Steele, Women, Press, and Politics; Tiernan, 'Tabloid Sensationalism', 74-87; and, Columbus, 'Bean na h-Éireann'.

${ }^{54}$ Accounts of Markievicz's militancy can be found in any of the histories of revolutionary Irish women cited in this article. For particular reference to the argument that Markievicz's memory has contributed to the historical amnesia about most other revolutionary women, see McCoole, No Ordinary Woman, 16; and, Matthews,

Renegades, 9. See also Steele, 'Constance Markievicz', 62-79.

55 'The Women of '98' (By Constance de Markievicz), The Irish Citizen 4, no. 256 (November 1915), 150.

56 'The Future of Irishwomen' (Speech delivered by Countess Markievicz at IWFL Meeting, October $12^{\text {th }}$ ), The Irish Citizen 4, no. 23 (23 October 1915), 137.

${ }^{57}$ For example, see Ward, Unmanageable Revolutionaries; Urquhart, Women in Ulster Politics; Cullen and Luddy, Female Activists; McCoole, No Ordinary Woman; Ryan \& Ward (eds.). Irish Women and Nationalism; Matthews, Renegades and Matthews, Dissidents; Pašeta, Irish Nationalist Women.

${ }^{58}$ Markievicz was also feminist in her aspirations. She was the first woman ever elected to the British House of Commons in 1919, although she refused to take her seat because of Sinn Féin's policy of abstentionism.

${ }^{59}$ For a more detailed discussion of nationalist feminist approaches to invoking a renewed sense of ancient Irish nationalism, see Crozier-De Rosa, 'Shame and Anti-Feminist Politics', 355-359.

60 'Sparks From The Anvil of War' (by Margaret E Cousins), Irish Citizen 3, no. 17 (12 September 1914), 132.

61 'Women's Rights', The Irish Citizen 3, no. 12 (8 August 1914), 93.

62 'Current Comment: A Contrast', The Irish Citizen 3, no. 20 (3 October 1914), 153.

${ }^{63}$ For an extended discussion of Irish feminist militants' defence of their violence, see the chapter 'The Shame of the Violent Woman' in Crozier-De Rosa, Shame and the Anti-Feminist Backlash, 193-230.

64 'The Movement in Ireland' (by F. Sheehy Skeffington), Votes for Women 4, no. 140 (11 November 1910$), 83$.

65 'Irish Women and Mr. Birrell', Votes for Women 4, no. 142 (25 November 1910), 132. 
${ }^{66}$ That Irish women had been left out of legislation that would have allowed English and Scottish women membership of County and Borough Councils brought home to the Irish the fact that until they fought on their own accord. The franchise would not necessarily be extended to them. The IWFL had established to achieve this end.

67 'The Movement in Ireland' (by F. Sheehy Skeffington), Votes for Women 4, no. 140 (11 November 1910), 83.

68 'Concerning Christabel', The Irish Citizen 3, no. 21 (10 October 1914), 166.

69 'Correspondence', The Irish Citizen 3, no. 20 (3 October 1914), 155.

70 'Correspondence', The Irish Citizen 3, no. 20 (3 October 1914), 155.

71 'The W.S.P.U. in Ireland', The Irish Citizen 1, no. 17 (17 September 1912), 130. Elizabeth Crawford has discussed this article in her blog. See Crawford, 'Suffrage Stories. For a brief discussion of the Irish Citizen's response to the 1912 WSPU actions, see Crawford, The Women's Movement, 267.

72 'The W.S.P.U. in Ireland', The Irish Citizen 1, no. 17 (17 September 1912), 130.

73 'Correspondence', The Irish Citizen 3, no. 20 (3 October 1914), 155. This sentiment was repeated, for example, one year later when militant suffragist, M. K. Connery, writing to the Irish Citizen, asserted: 'I would like to also point out that Miss Pankhurst, though admirable in her own country, which she thoroughly understood, has never founded or led anything in Ireland.' See 'Correspondence', The Irish Citizen 3, no. 38 (6 February 1915), 290.

74 'Correspondence', The Irish Citizen 3, no. 20 (3 October 1914), 155.

75 'Concerning Christabel', The Irish Citizen 3, no. 21 (10 October 1914), 166.

76 The Pethick Lawrences continued to campaign and to publish Votes for Women during the war but, as explained earlier, the Pankhursts channelled their energies into the war effort and transformed the WSPU paper, The Suffragette, into the much more jingoistic Britannia.

77 'Ireland and the German Peril', Britannia 1, no. 11 (17 August 1917), 84. This is an extract from a speech that Christabel Pankhurst gave at Queen's Hall on $26^{\text {th }}$ July 1917 which was first printed in the paper on $3^{\text {rd }}$ August and reprinted by request later in the month.

78 'Ireland and the German Peril', Britannia 1, no. 11 (17 August 1917), 84. Many of these sentiments, including those ascribed to Meyers, were repeated later in the year. See 'German Designs on Ireland', Britannia 1, no. 14 (7 September 1917), 111; and, 'German Designs on Ireland', Britannia 1, no. 21 (26 October 1917), 162.

79 'Ireland and the German Peril', Britannia 1, no. 11 (17 August 1917), 84.

80 'Ireland and the German Peril', Britannia 1, no. 11 (17 August 1917), 84.

81 'Ireland and the German Peril', Britannia 1, no. 11 (17 August 1917), 84.

82 'Ireland and Germany', Britannia 1, no. 10 (10 August 1917), 80.

83 'Ireland and the German Peril', Britannia 1, no. 11 (17 August 1917), 84. Later that year, Britannia announced that the radical nationalist movement in Ireland was not really a distinctly Irish movement. Along with other disruptive movements like Leninism in Russia and MacDonaldism in England (referring to the Labour policies of Ramsay MacDonald), it was simply part of a global phenomenon leading towards chaos and the breakdown of order. See 'German Designs on Ireland', Britannia 1, no. 14 (7 September 1917), 111.

${ }^{84}$ McClintock argues that as nineteenth-century Britain viewed woman's subordination to man and child's to adult as 'a natural fact,' then 'the family' was as useful image to summon when referring to other 'natural' hierarchies - 'the 'national family,' the global 'family of nations,' the colony as a 'family of black children ruled over by a white father'. McClintock, 'No Longer in a Future Heaven', 91.

${ }^{85}$ Hage, White Nation, 88.

${ }^{86}$ For a discussion of this discourse of 'enrichment', see Hage, 94.

${ }^{87}$ Hage, White Nation, 99.

\section{References}

Iriye, Akira. 'Transnational History'. Contemporary European History 13, no. 2 (2004): 211-222.

Blackwell, Maylei, Laura Briggs and Mignonette Chiu. 'Transnational Feminisms Roundtable'. Frontiers 36, no. 3 (2015): 1-24.

Chaudhuri, Nupur and Margaret Strobel (ed.s). Western Women and Imperialism: Complicity and Resistance. Bloomington and Indianapolis: Indiana University Press, 1992.

Columbus, Brittany. 'Bean na h-Éireann: Feminism and Nationalism in an Irish Journal, 1908-1911'. Voces Novae. Chapman University Historical Review 1, no. 1 (2009).

Crawford, Elizabeth. 'Suffrage Stories: "We believe that the rousing of the Irish People had best be left to Irish Women". Woman and her Sphere: http://womanandhersphere.com/2014/04/29/suffrage-storieswebelieve-that-the-rousing-of-the-irish-people-had-best-be-left-to-irish-women/, accessed 16 February 2016. 
Crawford, Elizabeth. The Women's Movement in Britain and Ireland: A Regional Survey. London: Routledge, 2005.

Crozier-De Rosa, Sharon. 'Marie Corelli's British New Women: A Threat to Empire?' History of the Family 14 (2009): 416-429.

Crozier-De Rosa, Sharon. 'Shame and Anti-Feminist Politics in Britain and Ireland: Drawing women back into the fold?' Australian Journal of Politics and History 60, no. 3 (2014): 346-359.

Crozier-De Rosa, Sharon. Shame and the Anti-Feminist Backlash, Britain, Ireland and Australia, 1890-1920. New York: Routledge, 2018.

Cullen, Mary and Maria Luddy (ed.s). Female Activists: Irish Women and Change, 1900-1960. Dublin: Woodfield, 2001.

Curthoys, Ann and Marilyn Lake. 'Introduction'. In Connected Worlds: History in Transnational Perspective, edited by Ann Curthoys and Marilyn Lake, 6-20. Canberra: ANU E-Press, 2005.

DiCenzo, Maria (with Lucy Delap and Leila Ryan). Feminist Media History. Suffrage, Periodicals and the Public Sphere. Basingstoke: Palgrave Macmillan, 2010.

Fletcher, Ian Christopher. "'Women of the Nations, Unite!” Transnational Suffragism in the United Kingdom, 1912-1914'. In Women's Suffrage in the British Empire. Citizenship, Nation and Race, edited by Ian Christopher Fletcher, Laura E. Nym Mayhall and Philippa Levine, 103-120. Abington, Oxfordshire, and New York: Routledge, 2002.

Gibbons, Luke. 'Race Against Time: Racial Discourse and Irish History'. In Cultures of Empire. Colonizers in Britain and the Empire in the Nineteenth and Twentieth Centuries. A Reader, edited by Catherine Hall, 207-223. Manchester: Manchester University Press, 2000.

Gibney, John. 'Early Modern Ireland: A British Atlantic Colony?' History Compass 6, no. 1 (2008): 172-182.

Hage, Ghassan. White Nation: Fantasies of White Supremacy in a Multicultural Society. Sydney: Pluto Press, 1998.

Hall, Catherine. 'Going a-Trolloping: Imperial man travels the Empire'. In Gender and Imperialism, edited by Clare Midgley, 180-199. Manchester: Manchester University Press, 1998.

Hannam, June, Mitzi Auchterlonie and Katherine Holden, International Encyclopedia of Women's Suffrage. Santa Barbara: ABC-CLIO, 2000.

Innes, C. L. “"A voice in directing the affairs of Ireland”: L'Irlande Libre, The Shan Van Vocht and Bean na hEireann'. In Irish Writing. Exile and Subversion, edited by Paul Hyland and Neil Sammells, 146-158. Basingstoke: Palgrave, 1991.

Kelly, Vivien. 'Irish Suffragettes at the Time of the Home Rule Crisis'. History Ireland 4, no. 1 (1996). http://www.historyireland.com/20th-century-contemporary-history/irish-suffragettes-at-the-time-ofthe-home-rule-crisis/

Knirck, Jason. Women of the Dáil: Gender, Republicanism and the Anglo-Irish Treaty. Dublin: Irish Academic Press, 2006.

Kumar, Krishan. 'Nation and Empire: English and British national identity in comparative perspective'. Theory and Society 29 (2000): 575-608.

Marks, Shula. 'History, the Nation and Empire: Sniping from the periphery'. History Workshop Journal 29, no. 1 (1990): 111-119.

Matthews, Ann. Dissidents. Irish Republican Women, 1923-1941. Dublin: Mercier Press, 2012.

Matthews, Ann. Renegades. Irish Republican Women 1900-1922. Dublin: Mercier Press, 2010.

McClintock, Anne. 'Family Feuds: gender, nationalism and the Family'. Feminist Review 44, (1993): 61-80.

McClintock, Anne. 'No Longer in a Future Heaven': Gender, Race and Nationalism.' In Dangerous Liaisons. Gender, Nation, and Postcolonial Perspectives, edited by Anne McClintock, Aamir Mufti and Ella Shohat, 89-112. Minneapolis: University of Minnesota Press, 1997.

McCoole, Sinéad. No Ordinary Woman. Irish Female Activists in the Revolutionary Years. Dublin: The O'Brien Press, 2003.

Miller, David. 'Colonialism and Academic Representations of the Troubles'. In Rethinking Northern Ireland. Culture, Ideology and Colonialism, edited by David Miller, 3-39. London and New York: Routledge, 1998.

Mohanty, Chandra. 'Under Western Eyes: Feminist Scholarship and Colonial Discourses'. Boundary 2 12, no. 3 (1986): 333-358.

Murphy, Cliona. 'Suffragists and Nationalism in Early Twentieth-Century Ireland. History of European Ideas 16, no.s 4-6 (1993): 1009-1015. 
Murphy, Cliona. The Women's Suffrage Movement and Irish Society in the Early Twentieth Century.

Hempstead, Hertfordshire: Harvester Wheatsheaf, 1989.

Murphy, William. Political Imprisonment and the Irish, 1912-1921. Oxford: Oxford University Press, 2014.

Owen, Rosemary Cullen. Smashing Times. Dublin: Attic Press, 1984.

Paisley, Fiona. 'Introduction'. Australian Feminist Studies 16, no. 36 (2001): 271-277.

Pašeta, Senia. Irish Nationalist Women, 1900-1918. Cambridge: Cambridge University Press, 2013.

Porter, Bernard. The Absent-Minded Imperialists: Empire, Society, and Culture in Britain. Oxford: Oxford University Press, 2004.

Purvis, June. Emmeline Pankhurst. A Biography. London: Routledge, 2002.

Rupp, Leila J. and Verta Taylor. 'Forging Feminist Identity in an International Movement: A Collective Identity Approach to Twentieth-Century Feminism'. Signs: Journal of Women in Culture and Society 24, no. 2 (1999): 363-386.

Ryan, Louise. 'A Question of Loyalty: War, Nation, and Feminism in Early Twentieth Century Ireland'. Women's Studies International Forum 20, no. 1 (1997): 21-32.

Ryan, Louise. 'The Irish Citizen, 1912-1920'. Saothar 17 (1995): 105-111.

Ryan, Louise. 'Traditions and Double Moral Standards: The Irish Suffragists' Critique of Nationalism'. Women's History Review 14, no. 4 (1995): 487-503.

Ryan, Louise \& Margaret Ward (eds.). Irish Women and Nationalism: Soldiers, New Women and Wicked Hags. Dublin: Irish Academic Press, 2004.

Sinha, Mrinalini, Donna Guy and Angela Woollacott (ed.s). 'Feminism and Internationalism' (special themed edition). Gender and History 10, no. 3 (1998): 345-600.

Steele, Karen. 'Constance Markievicz and the Politics of Memory'. In Irish Women and Nationalism: Soldiers, New Women and Wicked Hags, edited by Louise Ryan and Margaret Ward, 62-79. Dublin: Irish Academic Press, 2004.

Steele, Karen. Women, Press, and Politics during the Irish Revival. Syracuse: Syracuse University Press, 2007.

Tiernan, Sonja. 'Tabloid Sensationalism or Revolutionary Feminism? The First-Wave Feminist Movement in an Irish Women's Periodical'. Irish Communications Review 12 (2010): 74-87.

Tyrrell, Ian. 'Comparative and transnational history'. Australian Feminist Studies 22, no. 52 (2007): 49-54.

Tyrrell, Ian. Woman's World/Woman's Empire: The Woman's Christian Temperance Union in International Perspective. Chapel Hill: University of North Carolina Press, 1991.

Urquhart, Diane. Women in Ulster Politics 1890-1940. Dublin: Irish Academic Press, 2000.

Ward, Margaret. 'Conflicting Interests: The British and Irish Suffrage Movements'. Feminist Review 50 (1995): 127-147.

Ward, Margaret. Unmanageable Revolutionaries: Women and Irish Nationalism. London: Pluto Press, 1983.

Ward, Margaret \& Louise Ryan (eds.). Irish Women and the Vote: Becoming Citizens. Dublin: Irish Academic Press, 2018.

Wellings, Ben. 'Empire-nation: National and Imperial Discourses in England'. Nations and Nationalism 8, no. 1 (2002): 95-109.

Young, Robert J. C. The Idea of English Ethnicity. Malden: Blackwell, 2008. 